Dept. of Food Hygiene,

Fac. of Vet. Med. Assiut Univ.

\title{
FECAL CONTAMINATION OF ICE CREAM MIX POWDER SOLD IN ASSIUT CITY
}

\author{
(With 4 Tables)
}

\author{
By \\ ENAS EL-PRINCE MOHAMED; \\ AMAL ALI ABDEL-HALEEM*; A.A. ABDEL-HAMEID \\ and MANAL MOHAMED AMIN ABDEL-RAHIM* \\ * Animal Health Institute, Assiut, Egypt
}

(Received at 16/12/2006)

التلوث القولونى البرازى لبودرة مخلوط الآيس كريم البباع فى مدينة أسيوط

إيناس البرنس محدل ، آمال على عبل الطليم ، أحدل عبل الحميد أحدل،



بالرغم من أن الآيس كريم يعتبر من منتجات الألبان الواسعة الانتشار، السهلة الهضم، ذات القيمة الغذائية العالية، و الذى ينتشر تداوله بين فئات كثيرة و أعمار مختلفة من المستهلكين، إلانيان أنه قد يتعرض، تحت ظروف الإنتاج المختلفة وكذللك التصنيع والتوزيع، للتلوث الميكروبي التهي بمختلف الأنواع الممرضة والتى تشكل خطورة لا يستهان بها على صحة المستهاتلك، ومنها الميكروبات القولونية البرازية، لذلك كانت هذه الدراسة على بودرة مخلوط الته الآيس كريم المباع



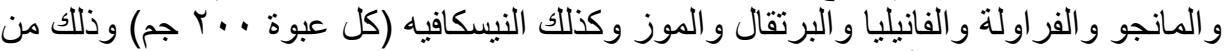

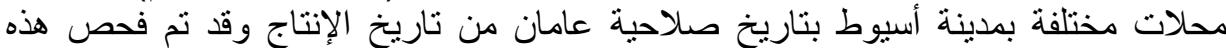

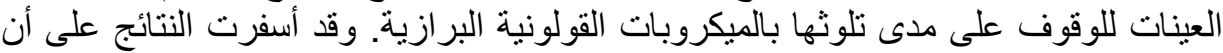

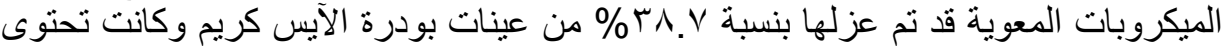

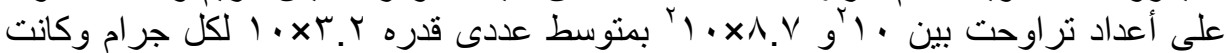

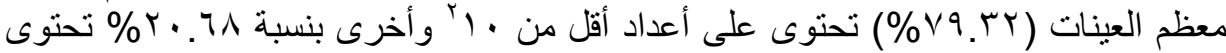

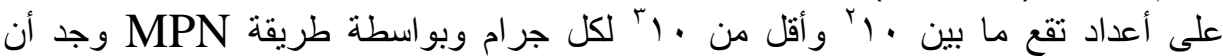
سب.

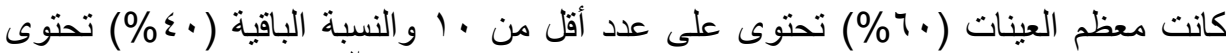

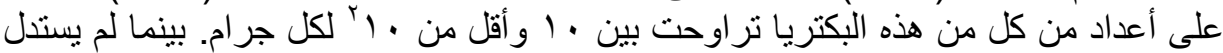

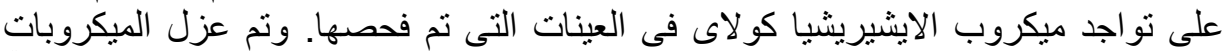

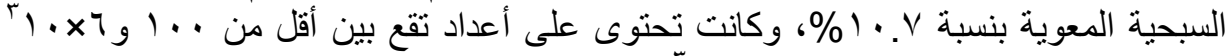

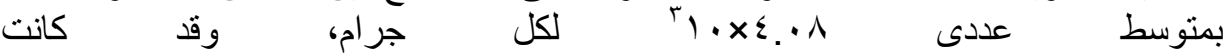

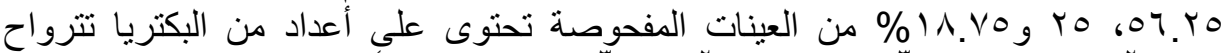

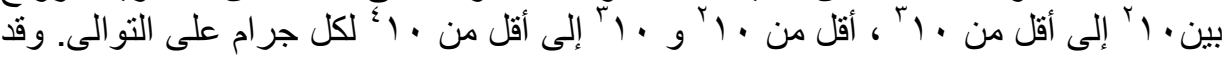




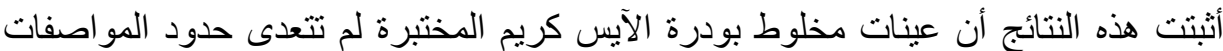

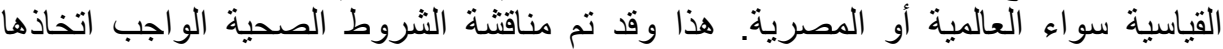
لإنتاج مخلوط بودرة آيس كريم ذو جودة عالية ولية وخالى من الميكروبات الممرضة المّة التى قد تشكل خطورة على صحة المستهلك.

\section{SUMMARY}

One hundred and fifty random samples of ice cream mix powder with chocolate, mango, strawberry, vanilla, orange, banana and Nescafe flavors (200 grams weigh each) were collected from different groceries and supermarkets in Assiut City over a period of one year and examined for fecal contamination. Our current results showed that, Enterobacteriaceae were isolated from $38.7 \%$ of samples with a minimum of $10^{2}$, a maximum of $8.7 \times 10^{2}$ and an average of $3.2 \times 10 / \mathrm{g}$. The highest frequency distribution $46(79.32 \%)$ had numbers of less than $10^{2} \mathrm{cfu} / \mathrm{g}$ and $12(20.68 \%)$ had counts ranged from $10^{2}-<10^{3} \mathrm{cfu} / \mathrm{g}$. Enterococci could be isolated from $10.7 \%$ of the examined samples with a minimum, a maximum and an average count of $<100,6 \times 10^{3}$ and $4.08 \times 10^{3} / \mathrm{g}$, respectively. The frequency distribution of positive samples was descending from $9(56.25 \%), 4(25.0 \%)$ and $3(18.75 \%)$ containing Enterococci in counts ranged from $10^{2-}<10^{3,}<10^{2}$ and $10^{3}-<10^{4} / \mathrm{g}$, respectively. Otherwise, $5(3.33 \%)$ samples were contaminated by both coliforms and fecal coliforms with frequency distribution of $3(60 \%)$ that had counts of less than 10/g and $2(40 \%)$ had counts ranged from $10-<10^{2} / g$. E. coli could not be detected. Recommendations were suggested to control the presence of such microorganisms in ice cream mix powder samples to avoid their undesirable changes that resulted in economic losses as well as public health hazard.

Key words: Enterobacteriaceac, coliforms, fecal coliforms, Enterococci, contamination, ice cream mix powder.

\section{INTRODUCTION}

Ice cream is the most palatable, nutritious, healthful and relatively inexpensive dairy food. It is highly appreciable by all ages because it is considered a safe, enjoyable, energy giving and refreshing food because levels of water soluble vitamins and minerals are two to three times higher than those of full cream milk. Also, it is a valuable source of vitamin $\mathrm{B}$, and contains twice vitamin A content as that of 
milk (Varnam and Sutherland, 1994). Nowadays, ice cream mix powder produced and sold in increasing quantities for manufacturing of ice cream on a large scale, in markets, and it is also purchased for preparation of ice cream at home. Ice cream mix is often stored (aging) for few hours or even overnight; so there is opportunity for bacterial growth and multiplication, rendering the product to be of public health hazard. Because ice cream is consumed without any treatment that might reduce its microbial load, it is necessary to maintain a high level of microbial quality. For this purpose, many countries have adopted mandatory manufacturing practices and standards to ensure an adequate and wholesome supply of such product.

In spite of the high temperature attained in preparation of ice cream mix powder and its low moisture content, its packaging process, addition of additives and flavoring agents, methods of preservation and transportation it may, at times, be responsible for transmitting some pathogenic and food poisoning bacteria to consumers. Their presence in dried milk products provides a useful index in determining the hygienic quality of the products. The presence of coliform bacteria in milk powder has been reported by Leitao et al. (1973); Aleksieva (1974); Jhodekeer and Nambudripad (1975); Jarchovská and Hartmanova (1975); Arun et al. (1980); and Lück et al. (1980). Enterococci organisms have a distinctive role as an indicator of poor factory sanitation; so that, they were enumerated and isolated from milk powder by many workers (Stark, 1970; Leitao et al., 1973; Aleksieva, 1974 and Lück et al., 1980).

As the microbial quality of ice cream mix powder with various flavoring agents, reflects the care with which milk was produced and the sanitary conditions prevailing during its manufactures, therefore, this work was planned to detect the fecal pollution by determination of Enterobacteriaceae, total coliforms, fecal coliforms, E.coli and Enterococci counts.

\section{MATERIALS and METHODS}

\section{A- Collection of the samples:}

150 random samples of ice cream mix powder with chocolate, mango, strawberry, vanilla, orange, banana and Nescafe flavors (200 grams weigh each) in retail packages ready for sale were collected from different groceries and supermarkets in Assiut City over a period of one year. The expired date was after 2 years, from the production time. To avoid contamination, the samples were dispatched directly to the 
laboratory where they were examined microbiologically to evaluate their quality.

\section{B- Preparation and serial dilution of samples:}

Packages of ice cream mix powder were cleaned and being aseptically opened. 11 grams of the ice cream mix powder samples were mixed with $99 \mathrm{ml}$ of sterile $0.1 \%$ peptone water and thoroughly mixed to have a dilution of 1/10 from which ten fold serial dilutions were prepared as recommended by A.P.H.A. (1992).

\section{C- Experimental techniques:}

\section{Included:}

1- Enumeration and isolation of Enterobacteriaceae using Violet Red Bile Glucose Agar (VRBGA). (Mercuri and Cox, 1979).

2- Total coliforms, fecal coliforms and E.coli counts using (MPN). (A.O.A.C., 1975).

3- Enumeration and isolation of Enterococci using $\mathrm{KF}$ streptococcal agar. (Deibel and Hartman, 1976).

\section{D- Biochemical reactions for Enterobacteriaceae organisms:}

\section{Included:}

1- Indol production, Methyl red, Voges-Proskauer, Citrate utilization, $\mathrm{H}_{2} \mathrm{~S}$ production tests: (Finegold and Martin, 1982)

2- Urease test: (Edwards and Ewing, 1972)

3- Glucose and sugar fermentation tests: (Speck, 1976)

\section{RESULTS}

The obtained results are recorded in Tables 1-4.

Table 1: Statistical analytical results of Enterobacteriaceae and Enterococci in the examined ice cream mix powder samples.

\begin{tabular}{|c|c|c|c|c|c|}
\hline \multirow{2}{*}{ Types of M.os } & \multicolumn{2}{|c|}{$\begin{array}{c}\text { Positive } \\
\text { samples }\end{array}$} & \multicolumn{3}{c|}{ Count/g } \\
\cline { 2 - 6 } & No./150 & $\%$ & Min. & Max. & Average \\
\hline Enterobacteriaceae & 58 & 38.7 & $*<100$ & $8.7 \times 10^{2}$ & $3.2 \times 10$ \\
\hline Enterococci & 16 & 10.7 & $*<100$ & $6 \times 10^{3}$ & $4.08 \times 10^{3}$ \\
\hline
\end{tabular}

*Colonies could not be detected on the plates. 
Table 2: Frequency distribution of the positive ice cream mix powder samples based on their Enterobacteriaceae and Enterococci count/g.

\begin{tabular}{|c|c|c|c|c|}
\hline \multirow{2}{*}{ Count/g } & \multicolumn{4}{|c|}{ Distribution } \\
\cline { 2 - 5 } & \multicolumn{2}{|c|}{ Enterobacteriaceae } & \multicolumn{2}{|c|}{ Enterococci } \\
\cline { 2 - 5 } & No. & $\%$ & No. & $\%$ \\
\hline$-<10^{2}$ & 46 & 79.32 & 4 & 25.00 \\
\hline $10^{2}-<10^{3}$ & 12 & 20.68 & 9 & 56.25 \\
\hline $10^{3}-<10^{4}$ & - & - & 3 & 18.75 \\
\hline Total & 58 & 100.00 & 16 & 100.00 \\
\hline
\end{tabular}

Table 3: Incidence of coliforms and fecal coliforms in the examined ice cream mix powder samples.

\begin{tabular}{|l|c|c|}
\hline \multirow{2}{*}{ Types of M.os } & \multicolumn{2}{|c|}{ Positive samples } \\
\cline { 2 - 3 } & No. $/ 150$ & $\%$ \\
\hline coliforms & 5 & $3.33 \%$ \\
\hline fecal coliforms & 5 & $3.33 \%$ \\
\hline
\end{tabular}

Table 4: Frequency distribution of positive ice cream mix powder samples based on their coliforms and fecal coliforms count (MPN/g).

\begin{tabular}{|c|c|c|c|c|}
\hline \multirow{2}{*}{ Count/g } & \multicolumn{4}{|c|}{ Distribution } \\
\cline { 2 - 5 } & \multicolumn{2}{|c|}{ coliforms } & \multicolumn{2}{c|}{ fecal coliforms } \\
\cline { 2 - 5 } & No. & $\%$ & No. & $\%$ \\
\hline $3-<10$ & 3 & 60.00 & 3 & 60.00 \\
\hline $10-<10^{2}$ & 2 & 40.00 & 2 & 40.00 \\
\hline Total & 5 & 100.00 & 5 & 100.00 \\
\hline
\end{tabular}

\section{DISCUSSION}

The results recorded in Table 1 revealed that, 58 (38.7\%) of the examined ice cream mix powder samples were contaminated by Enterobacteriaceae in counts ranged from $<100$ to $8.7 \times 10^{2}$ with an average count of $3.2 \times 10 \mathrm{cfu} / \mathrm{g}$. Table 2 showed that, most of positive 
samples $46(79.32 \%)$ contained numbers less than $10^{2} \mathrm{cfu} / \mathrm{g}$, while, 12 (20.68\%) had counts ranged from $10^{2}$ to $<10^{3} \mathrm{cfu} / \mathrm{g}$. These counts are in fair agreement with those recorded by Abdel-Haleem (1998) in ice cream mix powder. But in milk powder, Sprang (1969) recorded lower incidence. While, higher counts were conducted by Dardir (2005).

Contamination of large numbers of ice cream mix powder samples with Enterobacteriaceae could be taken as an index of fecal contamination and also could be attributed to the unsanitary practices, poor hygienic quality of ingredients used and/or may be due to the contamination during packaging.

Regarding the Enterococci counts, it is evident that $16(10.7 \%)$ samples contaminated with Enterococci. The level of contamination varied from $<100$ to $6 \times 10^{3}$ with an average of $4.08 \times 10^{3} / \mathrm{g}$. The frequency distribution arranged descending from $9(56.25 \%), 4(25.0 \%)$ and $3(18.75 \%)$ samples ranged from $10^{2-}<10^{3,}<10^{2}$ and $10^{3}-<10^{4} / \mathrm{g}$, respectively (Table 1 and 2). Higher counts and incidences were estimated by El-Bassiony and Aboul-Khier (1983) and Abdel-Haleem (1998) in ice cream mix powder samples. While, Aleksieva (1974) recorded higher counts in milk powder samples.

The occurrence of Enterococci in ice cream mix powder samples seems to be illogic, because no acceptable level of these microorganisms could be present, and may be attributed to post manufacture contamination, the heat resistant character of the organisms, and contamination during packaging and/or improper methods of distribution. The public health significance can not be denied, especially, when the organisms found in tremendous number in the product as they have been implicated in several food poisoning outbreaks (International Committee on Microbiological Specification for Foods (ICMSF), 1978).

It is clearly evident from the results illustrated in Table 3, that both coliforms and fecal coliforms could be isolated from 5 out of 150 samples $(3.33 \%)$. Most of positive samples $3(60 \%)$ contained coliforms and fecal coliforms less than $10 \mathrm{cfu} / \mathrm{g}$. While, $2(40 \%)$ had counts varied from $10-<10^{2} \mathrm{cfu} / \mathrm{g}$ (Table 4). Higher incidence of total coliforms was established by El-Bassiony and Aboul-Khier (1983). World Health Organization Standards (1981) reported that coliforms should fail to be detected in the examined ice cream mix powder samples. By comparing these counts with Egyptian Standard (1988), Varnam and Sutherland (1994) and U.S. Dairy Export Council (1996-2002) standards, coliforms counts did not exceed these standards. 
In case of fecal coliforms, nearly similar results were recorded by Aleksieva (1974) in infant dried milk samples. In the contrary, El-Prince and Korashy (2003) could not isolate these organisms from the examined milk powder samples.

Fortunately, E. coli could not be detected in all of examined ice cream mix powder samples. Coliforms contamination could be attributed to poor quality ingredients, careless hygiene during packaging. Moreover, coliforms and fecal coliforms still continue to be considered as indicator organisms of choice in examining milk and milk products (Marier et al., 1973).

As good sanitation and strict hygienic measures during processing, packaging, preservation and transportation of these desserts is fundamental, therefore, suggestive measures for control of microorganisms are to be considered to ensure safety and high quality ice cream mix.

\section{REFERENCES}

A.O.A.C. (1975): Association of Official Analytical Chemists Official Methods for Analysis, $21^{\text {st }}$ Ed., Washington, D.C.

A.P.H.A. (1992): Standard Methods for the Examination of Dairy Products. $16^{\text {th }}$ Ed., American Public Health Association, New York.

Abdel-Haleem, Amal, A. (1998): Bacterial contamination of ice cream mix powder in Assiut City. Alex. J. Vet. Sci., 14: 53-61.

Aleksieva, V. (1974): Enterococci in dried milk. Veterinarmeditsiaski Nauki, 11, 72. Dairy Sci. Abst., 37: 36 (1975).

Arun, A.P.S.; Prasad, C.R.; Basant, K.S. and Prasad, B.N. (1980): Occurrence of coliform bacteria in skim milk powder. Indian J. Dairy Sci., 33(1): 119-122.

Dardir, H.A. (2005): Health threatening of Enterobacter sakazakii associated with infant food. J. Egypt. Vet. Med. Assoc., 65(2): 7-13.

Deibel, R.H. and Hartman, P.A. (1976): The Enterococci. In: Compendium of Methods for the Microbiological Examination of Foods. M. L. Speck $2^{\text {nd }}$ Ed., American Public Health Association, Inc.

Edwards, P.R. and Ewing, W.H. (1972): Identification of Enterobacteriaceae. $3^{\text {rd }}$ Ed., Burgess Pub. Co., Minneapolis, Minnesota. 
Egyptian Standard (1988): Dried Milk. Egyptian Organization for Standardization and Quality Control (1648-988).

El-Bassiony, T.A. and Aboul-Khier, F.A. (1983): Bacteriological evaluation of dried milk products produced in Sakha processing dairy plant. Assiut Vet. Med. J., 11(21): 159-163.

El-Prince, Enas, M. and Korashy, Eman, A. (2003): Microbiological quality of dried milk based infant foods in Assiut city. Assiut Vet. Med. J., 49(97): 190-203.

Finegold, S.M., and Martin, W.J. (1982): Bailley and Scott Diagnostic Microbiology. $6^{\text {th }}$ Ed., C.V. Mosby Co., St. Louis, Toronto, London.

International Committee on Microbiological Specification for Foods (ICMSF) (1978): Microorganisms in Food. Their significance and methods of enumeration. $2^{\text {nd }}$ Ed., Univ. of Toronto Press, Toronto, Buffalo London.

Jarchovská and Hartmanová (1975): Incidences of Gram-negative organisms in dried milk product. Veterinatstvi, 25: 399. Dairy Sci. Abst., 38: 693 (1976).

Jhodekeer, D.R. and Nambudripad, V.K.N. (1975): Indian J. Dairy Sci., 28: 215 (Cited after Arun et al., 1980).

Leitao, M.F.D.; Delazari, I. and Mazzoni, H. (1973): Microbiology of dehydrated foods. Coletanea do Instotute Technologia do Alimentes, 5: 223. Dairy Sci. Abst. 37: 590 (1975).

Lück, H.; Gordaan, I. and Dunkeld, M. (1980): Incidence of pathogenic and other undesirable bacteria in milk powder. South African J. Dairy Technol., 12(2): 51-56.

Marier, R.; Wells, J.G; Swanson, R.C.; Callahan, W. and Mehlman, L.J. (1973): An outbreak of enteropathogenic E.coli food borne disease traced to imported French cheeses. Lancet, 2:1376.

Mercuri, A.J. and Cox, N.A. (1979): Coliforms and Enterobacteriaceae isolates from selected foods. J. Food Prot., 42(9): 712.

Speck, M.L. (1976): Compendium of Methods for the Microbiological Examination of Foods. $2^{\text {nd }}$ Ed., Printing. American Public Health Association, Inc.

Sprang, F.J. Van (1969): Bacteriological requirements for dried infant and weaning foods. (In" the microbiology of dried food. Proceedings of the sixth International Symposium on Food Microbiology") pp.: 496-510. Dairy Sci. Abst., 32: 2563 (1970).

Stark, E. (1970): Fecal Streptococci on barley, malt kernels and instant milk powder. J. Appl. Microbiol., 20: 2000. 
U.S. Dairy Export Council (1996-2002): U.S. Standards for milk powders. American Dairy Products Institute, Bulletin 916.

Varnam, A.H. and Sutherland, J.P. (1994): Milk and Milk Products, Technology, Chemistry and Microbiology. $1^{\text {st }}$ Ed., Chapman and Hall Pub., London.

World Health Organization Standards (1981): Nutrition and Food Safety Spain. Int. Digest of Health Legislation, 32(4): 781-783. Dairy Sci. Abst., 45: 186 (1983). 